\title{
Natural to anthropogenic influence of environmental change of Jakarta Bay: seismic reflection and sediment coring studies
}

\author{
Haryadi Permana ${ }^{1}$, Nugroho Dwi Hananto ${ }^{1}$ \\ ${ }^{1}$ Research Center for Geotechnology LIPI, Bandung, \\ Ph: +62 22250 3654; Fax: +62 22250 4593; email: hpharper.permana@ gmail.com \\ Rina Zuraida ${ }^{2}$, Susilohadi1 ${ }^{2}$, Kresna Tri Dewi ${ }^{2}$, Mustaba Ari. Suryoko ${ }^{2}$, Nazar Nurdin ${ }^{2}$ \\ Eko Saputro ${ }^{2}$, Adi C. Sinaga ${ }^{2}$ \\ ${ }^{2}$ Marine Geological Institute, ESDM, Bandung, email: rinazuraida@yahoo.com \\ Septriono Hary. Nugroho ${ }^{3}$ \\ ${ }^{3}$ Research Center for Oceanography LIPI, Ambon,email: h4rry_nugroho@yahoo.com
}

\begin{abstract}
The shallow of high resolution seismic reflection profiles recorded dynamic development of Jakarta Bay. The interpretation results suggest least four transgression events and three events of regression. The last regression event characterized by rough erosional surface, deep and wide channel of fluvial or shallow marine environment. This event indicates strong energy sedimentation accompanied by high density material flow like as laharic flows or dense and frequent wet season. Upper part of seismic profile characterized by continues, parallel and thin sedimentation layer indicates gradual sea transgression event. The shallow sediment coring data, $100 \mathrm{~cm}$ to $160 \mathrm{~cm}$ length, indicates significant anthropogenic influences. At the depth $50 \mathrm{~cm}$, the sediment core shows decreasing sharply of $\mathrm{Si}, \mathrm{Ca}, \mathrm{Ti}$ and $\mathrm{Fe}$ content interpreted as decreasing of volcanic source rocks. While to the near sediment surface was indicated by increasing of major element content such as $\mathrm{Cu}, \mathrm{Ti}$ and $\mathrm{Fe}$ and also the heavy metals content such as $\mathrm{Pb}, \mathrm{Cr}, \mathrm{Cd}, \mathrm{Sn}$ and $\mathrm{Zn}$. The presence of major or heavy metals were possible related to human activities such as deforestation, industry, transportation and agriculture while in depth, the heavy metal content related to volcanic rocks as source rocks The environmental degradation in modern period detected at the sediment surface indicated by increasing sharply of Ammonia.
\end{abstract}

Keywords : Shallow Sediment, Seismic Reflection, Antropogic Influence 


\section{Introduction}

Environmental waters of eastern and southern Sumatra, Java Sea, Karimata Strait, and the Sunda Strait has changed extremely since the formation of Sunda Shelf during the last Ice Age (Hanebuth et al., 2000; Voris, 2000), and Bird et al. (2005) conducted a detailed study of ancient environment in the region. However, the effect of the formation of the Java Sea or the waters between Java and Sumatra and Borneo to the monsoon system in the region is not really understood yet. For these reasons, the reconstruction of the ancient environment is very important, particularly through the study of ancient climates and environments. This study will focus on understanding the evolution of environmental change inferred from seismic reflection data and using drill core of surface sediments seafloor derived from the Jakarta Bay (TJ-17) that is already available through several expeditions of Marine Geological Institute-ESDM. The seafloor of Java Sea region is tectonically stable since the Late Pleistocene. An intensive study of the role of El Niño / Southern Oscillation (ENSO) and climate system in Indonesian monsoon variations over the time scale ranges from the last 1000 years, approximately the Holocene until the end of the Ice Age will obtain the dynamics of the environment changes, with or without human interference. To be able to estimate the modern climate variations, it is necessary to understanding the dynamics of climate change from time to time so that the necessary understanding of variations in past climate change by reconstructing the ecological changes in the past.

\section{Study Area, Objective and Method}

This short paper is part of the report activity 2013 of the SiNas Program under Kemenristek program that focus on the environmental change aspects due to natural or anthropogenic effect inferred from seismic reflection and sea surface sediment core of the Jakarta Bay. The data was conducted in 2010 during MGI -ESDM survey (Zuraida et al., 2010). Figure 1 shows the location of the reflection seismic activity in the Bay of Jakarta and Coring location of TJ-17 while Figure 2 is a cross-sectional analysis of the location and seismic reflection elected.

This study aims to improve understanding of the influence of human behavior and its impact on the environment from the point of view the climate change every time. This knowledge will be useful in planning future development and management of the coastal environment. The Jakarta Bay represents a region that can better reflect environmental changes due to climate-related natural and human activities such as industrialization, agricultural or otherwise. For the analysis, it is assumed wave velocity in sedimentary rocks (soft) of $2000 \mathrm{~m} / \mathrm{s}$ or every $25 \mathrm{~m} / \mathrm{s}$ correlate to thickness or depth of $6.25 \mathrm{~m}$. Figure 3 is a seismic reflection cross section and analyses.

The TJ-17 core of Foraminifera observations and analyses carried out on drill core sediment at intervals of $5 \mathrm{~cm}$ to a depth of $50 \mathrm{~cm}$ and then $10 \mathrm{~cm}$ intervals at depths below $50 \mathrm{~cm}$. The analysis shows fluctuations plankton content of foraminifera in sediments as indicator of environmental change.

\section{Literature Review}

The Earth climate variation experienced was well documented in the sedimentary rocks that were deposited on the surface of the seafloor. In the Indian Ocean region, climate or 
temperature changes or variations have been recorded since the Early Miocene (21.8 to 17.6 million years ago $(\mathrm{Ma})$ or Late Oligocene $(25 \mathrm{Ma})$ is characterized by warmer sea surface temperatures are constantly up to Middle Miocene or 13-14 Ma (Srinivasan and Chaturverdi, 1990). Maximum warmer temperatures were followed by temperate in Middle Miocene in the tropics regions due to ice caps melting in Antarctica to set up temperate temperatures around tropical Indian Ocean region (Srinivasan and Chaturverdi, 1990). In the Middle Miocene (11-12 Ma), important changes were possible by disconnecting of the equatorial of Indian Ocean region with Pacific Ocean region (Kennett et al., 1985). Environmental changes or variations in climate (temperature) at the time strongly influenced by tectonics activities such as formation of outer-arc and volcanic-arc or land up lifted of the Java or Sumatra region or Antarctic ice caps melting. At the end of the Miocene (6.2 Ma), global cooling occurs and followed by sea level drop (regression) that might be associated the occurrence of global climate change and tectonic events or land up lifting. A temperature variability continues as recorded in Early Pliocene $(5.2 \mathrm{Ma})$ and Late Pliocene $(1.8 \mathrm{Ma})$, that are characterized by cooling sea surface temperatures. Sea surface temperature decreases continuously during the Pleistocene cause spread out of tempera temperatures due in the tropical region. The data suggest, in the past, a climate variations and environmental changes over controlled by natural events such as tectonic activity that causes an increase or decrease in relative sea level. Later, volcano activity also can cause the Earth's temperature and the relative increase can be followed by melting polar ice caps.

In the modern era, climate or temperature variations are characterized by increased in sea surface temperatures (SSTs) as recorded in the Timor region (Cahyarini, al,, 2009). Meanwhile, in the Siberut and Mentawai Islands, a sea surface temperature was increased about $3.2^{\circ} \mathrm{C}$ over a period of 11 years in the 14th century (Cahyarini, SY, 2010). Extreme environmental changes supposedly followed the climate change or climate variations in the Southeast Asia caused by sea level rise to $120 \mathrm{~m}$ at the optimum the last Ice Age about 20-17 thousand years ago (Voris, 2000). The Sunda and Sahul Shelf had been sinking and separated the island of Sumatra, Kalimantan and Java and also Papua and Australia (Voris, 2000). This transgression event, in consequently was decreased rivers gradient and causes decreased rate of sedimentation.

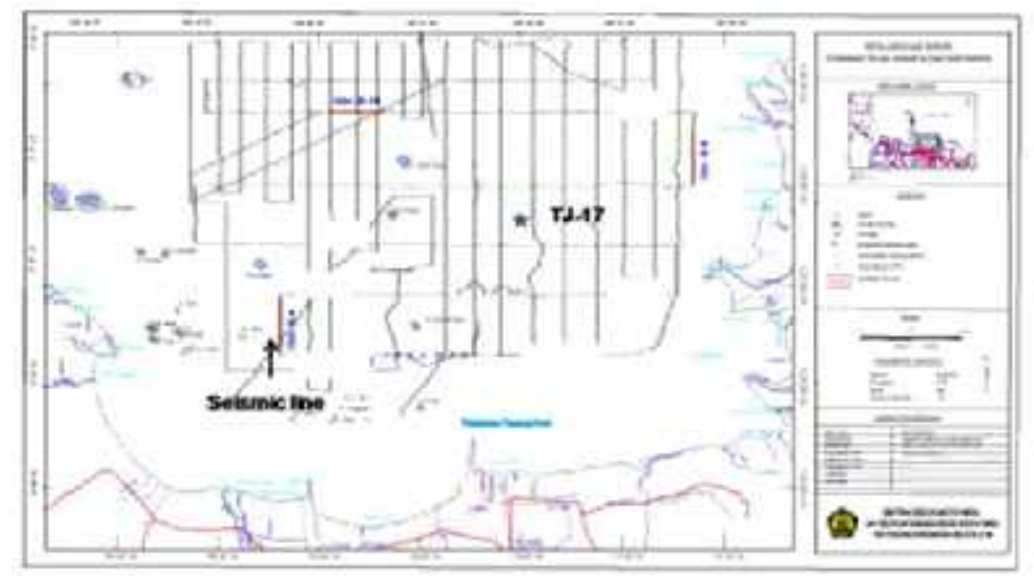

Figure 1. Seismic line and core sample (TJ-17) location

Since the end of the ice age, Sundaland area environment changes drastically. Human activities such as mining, farming, logging or industrialization has led to the mountainous 
region along the island of Sumatra, Java and Kalimantan to be open and experience the intense erosion due to the wet season with high rainfall.

\section{Result and Discussion}

\section{Result}

Results

In this paper present seismic reflection cross section interpretation (Figure 2), $2 \mathrm{~km}$ long, north-south in direction and $6 \mathrm{~m}$ depth, located approximately $9 \mathrm{~km}$ to the north of modern Ciliwung River (Figure 2). Total thickness of seismic reflection cross section about 49-50 m.

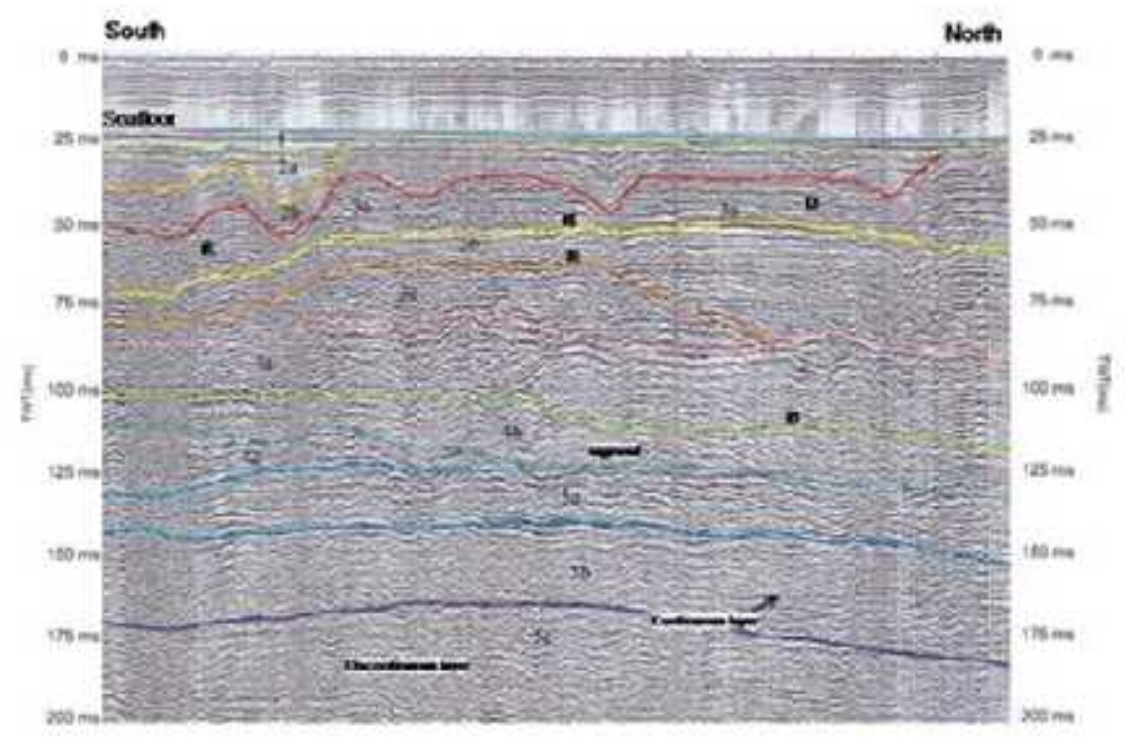

Figure 2. Interpretation of seismic reflection in northern modern Ciliwung River, Jakarta Bay

The seismic cross section shows development of the northern coastal area of Jakarta Bay. The left side is mainland (south), while the open sea (north) or modern offshore area at right side. There is no indication of the fault activity for the whole seismic image that indicate no tectonic activity had done or the study area is tectonically stable condition.

The seismic reflection can be identified about 5 unit rock layers. The older layer is $5 \mathrm{c}$ layer at depth of 42.5 to $45 \mathrm{~m}$ from the sea floor that is characterized by rough or strong reflector. On the south side, sediment layer was dominated a relatively discontinuous layer or short sigmoidal which interpreted as terrestrial sediments (fluvial) or transition, while to the north is characterized by a continuous layer that interpreted as shallow marine environment (Fig. 2, layer 5c). Other continuous, fine and steep -angle of sigmoidal layers estimated deposits in the delta environment.

The layer $5 \mathrm{~b}$, about $6.25 \mathrm{~m}$ thick illustrates more extensive continuous layer indicate gradually transition (5c to 5a) into the marine environment (Onlap) until the middle section. While, on the south side, the rough surface erosion may characterizes a terrestrial or fluvial environment. Depositional environments ranging from delta to shallow marine 
at the north side of the cross-sectional developed 5a layer that is characterized by coarse continuous layer about 4.25 to $5.75 \mathrm{~m}$ thick. The formation of layer $5 \mathrm{a}$ was dominated by moderate to coarse grained sediment under strong energy deposition. Sediment deposition is continuous form layer $4 \mathrm{c}, 1.25$ to $3.75 \mathrm{~m}$ thick with wedge shape. The bottom of $4 \mathrm{~b}$ layer is characterized by surface erosion, which indicates important in environmental conditions changes. Wedge shape of the layer itself indicates the occurrence of fast marine regression to lead an environmental change by terrestrial or fluvial followed by erosion processes and formation of canals. The $4 \mathrm{~b}$ layer, 1.25 to $3.75 \mathrm{~m}$ thick is discontinuous layer, a sigmoidal shape and canals characterize terrestrial environments with minimal sediment supply. The terrestrial environmental conditions continually to $4 \mathrm{a}$ Layer on the south side and it was characterized by a continuous layer and canals shape are interpreted as fluvial environment deposition (river sediment) and coastal or shallow marine environments and also delta formation that is characterized by a steep angle sigmoidal form on the north side indicate marine environment with low energy and minimal sediment supply. The 4a layer thickness varies from $2.5 \mathrm{~m}$ in the south up to 7.5 $\mathrm{m}$ on the north side. Fluvial environmental conditions uninterrupted toward younger $3 \mathrm{c}$ layers, with thickness varying from 1.25 to $3.75 \mathrm{~m}$ that is characterized by a discontinuous layer, channels forms or nicks. The important events of transgression recorded in $3 \mathrm{~b}$ layer. It is characterized by a continuous bedding cover or eroded the $3 \mathrm{c}$ layer to form wedge shape and offlap at the bottom layer transform into Onlap at the top bedding at the northern section. Continuous bedding is characteristic of $3 \mathrm{~b}$ layers and it was interpreted as marine sediments with a thickness of $6.5 \mathrm{~m}$ and generally thinning toward the south section about $1.25 \mathrm{~m}$. A coral growth (reef or R, in Figure 2) observed as bending layer forms. Marine environment constantly develops until the bottom of the 3a layer accompanied by coral growth (R), and delta formation (D) in the northern part of the section that is characterized by large-angle of sigmoidal layer, continuous coral growth (R) and a shallow marine environment in the south side of the cross section. The 3a layer thickness is remaining varies between 2-3 m due to strong erosion formed a deep valleys and wide $\mathrm{V}$ or $\mathrm{U}$-shaped valley with a relative depth about 2 to $4 \mathrm{~m}$. These valleys are part of river valley (fluvial) in the south section and become a valley in a shallow marine environment in the middle and on the north side of section to form the $2 b$ layer with a thickness varies about $2.5 \mathrm{~m}$ to $5 \mathrm{~m}$. These events possibly associated with the addition of high density of sediment volume or very strong energy of sedimentation so that to form valleys or submarine channels and eroded the 3a layer. Deposition in terrestrial environments is continuous in the southern section (Layer 2b) but in the middle and northern section filled by shallow marine sediment deposits and canals ( $2 \mathrm{~b}$ ) and corals growth $(\mathrm{R})$ in transition region. The $2 \mathrm{~b}$ layer has a thickness ranging from $2.5 \mathrm{~m}$ to $5 \mathrm{~m}$ thick. On the north side section, marine environment deposition is continuous while at the south side was dominated by rivers or shallow marine environment sedimentation with a thickness about 1.75 to $3.25 \mathrm{~m}$ (2a layer) and continuation of coral growth. The youngest bedding is fine and soft sediments of shallow marine environment indicate relatively low energy sedimentation with a thickness of $80 \mathrm{~cm}$ to $1.5 \mathrm{~m}$ (1 layer).

\section{Coring Analyses}

The shallow sediment coring data (TJ-17; Figure 1), $100 \mathrm{~cm}$ to $160 \mathrm{~cm}$ length, indicates significant anthropogenic influences. The main elements are utilized in this study include silicon ( $\mathrm{Si}$ ), titanium (Ti), iron $(\mathrm{Fe})$, and calcium $(\mathrm{Ca})$. The $\mathrm{Si}$ and $\mathrm{Ca}$ element content shows uniformity pattern up to a depth of $155 \mathrm{~cm}-135 \mathrm{~cm}$. Ca content increases ranging from a depth of $135 \mathrm{~cm}$ to a depth of $100 \mathrm{~cm}$ while the Si content fluctuates. Ca content 
decreased rapidly to a depth of $50 \mathrm{~cm}$ while Si decreases slowly. The content of $\mathrm{Si}$ and $\mathrm{Ca}$ decreased significantly starting from a depth of $50 \mathrm{~cm}$ to the surface of the drill core.

Metal content of Titanium (Ti), iron $(\mathrm{Fe})$ and copper $(\mathrm{Cu})$ in drill core vary greatly decreased for $\mathrm{Ti}$ and $\mathrm{Fe}$ but increase content of $\mathrm{Cu}$ from a depth of $150 \mathrm{~cm}$ and a slight increase in the depth of $105 \mathrm{~cm}$ for $\mathrm{Ti}$. Ti and $\mathrm{Fe}$ elements content decreased rapidly from a depth of $50 \mathrm{~cm}$, while $\mathrm{Cu}$ is slowly rising. $\mathrm{Cu}$ rapidly ascending at a depth of $20 \mathrm{~cm}$ while the $\mathrm{Ti}$ and $\mathrm{Fe}$ decreased strongly at a depth of $25 \mathrm{~cm}$ followed later by an increase $\mathrm{Ti}$ and Fe near the surface.

The heavy metals content in the bottom of the drill core is sourced from nature like as from $\mathrm{PbS}$ (galena), $\mathrm{PbCO} 3$ (cerusite) and $\mathrm{PbSO} 4$ (anglesite) minerals, while a heavy metals content on the surface most likely comes from human activities such as industry or industrial waste, and agricultural fertilizer. The content of $\mathrm{Pb}, \mathrm{Zn}$ and $\mathrm{Cr}$ (also $\mathrm{Cu}$ ) have the same pattern in nature is likely due to a massive sulfide minerals group such as $\mathrm{Cu}$ $\mathrm{Pb}-\mathrm{Zn}$ are often found in volcanic areas. Chrome or chromium, $\mathrm{Cr}$ is often found in volcanic rocks as chromium oxide $\mathrm{FeCr} 2 \mathrm{O} 4$, while $\mathrm{Sn}$, tin is present in nature as the mineral cassiterite or tin oxide $\mathrm{SnO} 2$.

Even, the heavy mineral of Cadmium, $\mathrm{Cd}$ and tin, $\mathrm{Sn}$ has a content varies pattern but they tend to decrease. Start from $60 \mathrm{~cm}$ depth, the $\mathrm{Cd}$ and $\mathrm{Sn}$ content increased strongly at a depth of $50 \mathrm{~cm}$ and then declined precipitously. Near the surface, the Sn content increased sharply followed by $\mathrm{Cd}$ might be associated with industrial and agricultural activities.

The Foraminifera observations carried out on sediment core at intervals of $5 \mathrm{~cm}$ to a depth of $50 \mathrm{~cm}$ and then $10 \mathrm{~cm}$ intervals at depths below $50 \mathrm{~cm}$. The analysis shows fluctuations plankton content of foraminifera in sediments.

Foraminifer plankton is common present in the open seas, so, fluctuation of the presence of foraminifer plankton in sediment could be indicated a change in ocean circulation. In addition, there were also fluctuations in the content of benthic foraminifer with porcelain shells that are generally owned by benthic foraminifer of the Miliolina ordo commonly found in high salinity. This probably reflects a change in salinity at the study site as observed at a depth of $25 \mathrm{~cm}$. Content fluctuations were also seen in the presence of Asterorotalia that can indicate the current strength of a region. Although fluctuations Asterorotalia seen in this example, but a comparison of the average grain size is nearly uniformly silt sized indicates that the current changes are not large enough to prevent the deposition of silt in the sediment. The sharply increase content of Ammonia at a depth of $20 \mathrm{~cm}$ showed a decrease in environmental quality causes a decrease in the number of species other than Ammonia. Increased environmental degradation is observed clearly from a depth of $20 \mathrm{~cm}$ where Ammonia sp sharp increase followed by a decrease Porcelain and comparison of plankton presence (P/B).

\section{Discussion}

The seismic reflection analysis of Jakarta Bay has been able to identify some of the environmental changes related to sea-level rise events or transgression, sea level drop or regression, due to reduced or increased sediment supply related to climate change (weather) or environmental degradation (Figure 3). The oldest layer (5c) in the seismic 
section estimated as the Cisubuh Formation, the Early Pleistocene age (Technical Reportnot published, 2010) which is deposited in terrestial and coastal environment.

Sea level rise event occurs in older bedding (5b-5a and 4c). Continuous bedding and coarse sediments of 5a layer were interpreted as sedimentation of medium-coarse grained material due to strong energy associated with the wet season. A transgression events uninterrupted until the south section (4c layer) as shown in Figure 2).

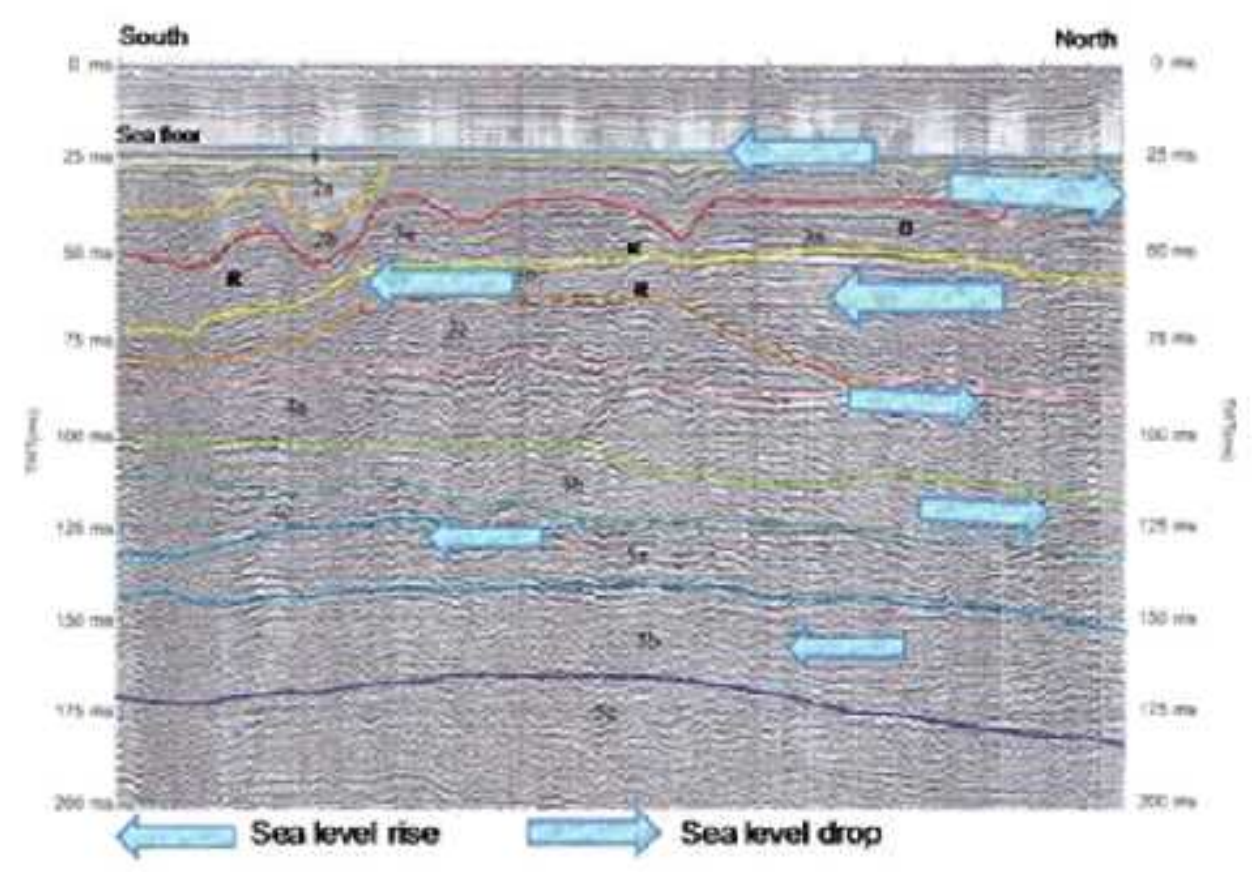

Figure 3. Environmental changes events interpreted from seismic reflection.

Sea level drop events was followed by depositional environment changes of $4 \mathrm{~b}$ Layer as terrestrial environment on the south side that eroded the bottom of $4 \mathrm{c}$ layer and delta environment (D) or shallow marine on the north side. The sea level drop events constantly to form the 4a layer in terrestrial or fluvial environments especially on the south side and the delta or a shallow marine environment in the north side. Canals or valley development (Ancient River?) within sediment filling indicates significant sediment supply in 4a Layer. This fact can be interpreted the strong erosion events on terrestrial region could be related to important wet season brings quite a lot of erosion materials. The 4a Layer developed at the north (right side) in transition, delta or shallow marine. A terrestrial environment conditions extended to $3 \mathrm{c}$ Layer is characterized by surface erosion as a respond to continuation of sea level drop event. Environmental conditions change drastically as a result of the sea level rise/transgression events that develop $3 b$ bedding that erode some of the $3 c$ layers. The $3 b$ bedding start form shallow marine environment, delta or coastal environments on the north side which gradually change into the marine environment. Coral $(\mathrm{R})$ at base of $3 \mathrm{c}$ layer (Thousand Islands?) grown in the transition condition at the north side region. A continuous sea level rise is forming 3a layer that is characterized by coastal environment on the south side and coral growth at the middle of section and delta (D) on the north side. Environmental conditions change rapidly due to sea level drop events that erode portion of the layer $3 \mathrm{a}$ surface. The 
3a layer was covered by $2 \mathrm{~b}$ Layer that deposit in terrestrial environment such as fluvial environment (rivers) within deep and wide valley. Strong erosion due to possible sedimentation energy or high density sediment material to form a wide and deep valley that might be associated with an intense wet season conditions. Sea level event gradually occur on the northern side of seismic section while at the south section remained terrestrial environments deposition to form Layer $2 a$ that eroded $2 b$ layer. The sea level gradually cover the entire of Jakarta Bay area that are characterized by continuous deposition of fine material of coastal and shallow marine environments to form the 1 layer.

Ups and downs of $\mathrm{Si}$ and $\mathrm{Ca}$ content might be associated with the sediments content deposited by rivers and are not associated with the fluctuations discharge or current due to relatively constant of grain size. When it were associated with sediment sources, the $\mathrm{Si}$ and $\mathrm{Ca}$ associated with volcanic deposit where the headwaters Bekasi River or Cigombong River. The $\mathrm{Si}$ and $\mathrm{Ca}$ contained in a feldspar mineral as volcanic products. The Si content decline start from $50 \mathrm{~cm}$ depth indicates a decrease or cessation of volcanic activity as a source of sediment. The Gede Pangrango volcano is active in the Quaternary period with 21 eruptions since 1747 until then less active since 1957 (Iguchi et al., www.dpri.kyoto-u.ac.jp/ kazan/13k02/iguchi.pdf). Moreover, the increase content of $\mathrm{Cu}, \mathrm{Ti}$ and $\mathrm{Fe}$ near the surface is most likely associated with industrial activities or other human activities began to be detected at a depth of $50 \mathrm{~cm}$. Such as $\mathrm{Si}$ and $\mathrm{Ca}, \mathrm{Ti}$ and Fe content decreases sharply at a depth of $50 \mathrm{~cm}$ associated with a decrease in sediment source of volcanic material.

The $\mathrm{Pb}, \mathrm{Cr}$, and $\mathrm{Zn}$ have relatively stable content with pattern rose toward the surface. The content of $\mathrm{Zn}$ slightly increased at a depth of $50 \mathrm{~cm}$ and $\mathrm{Pb}, \mathrm{Cr}$, and $\mathrm{Zn}$ content start increased constantly at depth of $20 \mathrm{~cm}$. Increased content of heavy metals in surface most likely related to human activities such as industry, transport and agriculture, while heavy metal content at the bottom layer is derived from volcanic rocks erosion or directly related to volcanic activity. The industrial and agricultural activities was indicated by the Sn content increased sharply followed by Cd near the surface. Increased environmental degradation is observed clearly from a depth of $20 \mathrm{~cm}$ where Ammonia sp sharp increase followed by a decrease Porcelain and comparison of plankton presence ( $\mathrm{P}$ / B).

\section{Concluding Remarks}

Seismic reflection analysis of Jakarta Bay has resulted in an understanding of the changes in the environmental conditions recorded in sedimentary rocks of the Jakarta Bay. Least 3 times the event of sea level rise and sea level drop events 2 times were happened in the past. Wet or dry season indication interpreted of rough or smooth layering form associated with sedimentation energy. Least 3 times of the wet season identified brings relative rough material or 3 times event of dry season that bring fine materials with minimal energy. The sea level drop event was followed by the formation of deep and wide valleys that can be interpreted as a result of the high energy sedimentation accompanied with high density material such as laharik flow or large and intense rainfall. The environment degradation well recorded in the sediment surface cause mostly from human activity. 


\section{REFERENCES}

Bird, M.I., Taylor, D., and Hunt, C. (2005). Palaeoenvironments of insular Southeast Asia during the Last Glacial Period: a savanna corridor in Sundaland? Quaternary Science Reviews, 24(20-21), (pp. 2228-2242).

Cahyarini, S.Y., Pfeiffer, M., dan Prayudi, D. (2009). Variasi Suhu Muka Laut Bulanan Berdasarkan Kandungan Kimia Koral. Teknologi Indonesia, no. 32 (2) 2009. (pp..115120)

Cahyarini, S.Y. (2010). Tren kenaikan suhu permukaan laut pada abad ke-14 berdasarkan data geokimia $\mathrm{Sr} / \mathrm{Ca}$ dari koral Mentawai. Jurnal Geologi Indonesia. Vo. 5, no. 2, juni 2010: (pp.113-118).

Hanebuth, T., Stattegger, K., and Grootes, P.M., 2000. Rapid Flooding of the Sunda Shelf: A Late-Glacial Sea-Level Record. Science, 288, 1033-1035.

Kennett, J. P.,Von der Borch, C., Baker, P. A., Barton, C. E., Boersma, A., Cauler, J. P., Dudley, W. C., Gardner, J. V., Jenkins, D. G., Lohman, W. H., Martini, E., Merrill, R. B., Morin, R., Nelson, C. S., Robert, C., Srinivasan, M. S., Stein, R., Takeuchi, A., Murphy, M. G. 1985. Palaeotectonic implications of increased late Eocene-early Oligocene volcanism from South Pacific DSDP sites.

Iguchi et al. 2012. www.dpri.kyoto-u.ac.jp / kazan/13k02/iguchi.pdf).

Laporan Teknis (tidak Terbit). 2010. Rona awal lingkungan serta potensi kebencanaan Teluk Jakarta sebagai bahan pertimbangan dalam melakukan reklamasi. Pusat Penelitian dan Pengembangan Geologi Kelautan, 2010 (tidak terbit)

Srinivasan, M. S., Chaturvedi, S. N. (1990). Neogene paleoceanographic events in the tropical Indian Ocean: evidences from quantitative planktonic foraminiferal analyses and isotopic record.OJI International Seminar for IGCP-246. pp. 65-73.

Voris, H.K., 2000. Maps of Pleistocene sea levels in Southeast Asia: shorelines, river systems and time durations. Journal of Biogeography, 27, 1153-1167.

Zuraida, R., Rahardiawan, R., Subarsyah, Dewi, K.T., Nugraha, H.W., Soeprapto, T.A., Yayu, N., Adhirana, I., Ibrahim, A., Saefudin, A., Subekti, A., Mulyono, Supriyatna, Heriyanto, dan Eko, D. 2010. Penelitian Lingkungan dan Kebencanaan Geologi Kelautan Perairan Teluk Jakarta (Tanjungkait-Muara Gembong). Laporan Kegiatan PPPGL TA 2010 . KESDM-Balitbang ESDM, PPPGL. 2010 (Tidak Terbit) 